\title{
PENGARUH DISIPLIN KERJA TERHADAP PRESTASI KERJA PEGAWAI PADA PUSKESMAS DI KECAMATAN DEPATI VII KABUPATEN KERINCI
}

\author{
PEBI JUliantO, S.Sos., MM., CHt. \\ STIA NUSANTARA SAKTI SUNGAI PENUH \\ Email : pebijulianto@gmail.com.com
}

\begin{abstract}
ABSTRAK
Penelitian ini bertujuan untuk mengetahui Pengaruh Disiplin Kerja Terhadap Prestasi Kerja Pegawai pada Puskesmas di Kecamatan Depati VII Kabupaten Kerinci, untuk mengetahui besarya pengaruh Disiplin Kerja Terhadap Prestasi Kerja Pegawai pada Puskesmas di Kecamatan Depati VII. Jenis penelitian ini adalah penelitian kuantitatif dimana berbicara dengan angka-angka serta melihat pengaruh antara variabel bebas (independen) dengan variabel terikat (dependent). Pada penelitian ini peneliti ingin melihat Pengaruh Disiplin Kerja Terhadap Prestasi Kerja Pegawai pada Puskesmas di Kecamatan Depati VII Kabupaten Kerinci. Hasil penelitian ini adalah Terdapat pengaruh disiplin terhadap prestasi kerja pegawai pada Puskesmas Kecamatan Depati VII Kabupaten Kerinci yang dihitung dengan korelasi sebesar 0,33, hal ini menunjukkan hubungan cukup kuat prerhitungan tingkat kesalahan 0,05 / 5\%, didapat t tabel 2,021 dan thitung 2,4470 dalam hal ini t hitung besar dari $t$ tabel yang berarti pengaruh disiplin Kerja terhadap prestasi kerja pegawai pada Puskesmas Kecamatan Depati VII Kabupaten Kerinci adalah signifikan. Besarnya pengaruh disiplin terhadap prestasi kerja pegawai pada Puskesmas Kecamatan Depati VII Kabupaten Kerinci adalah sebesar 10,89\%, sisanya 89,11\% dipengaruhi oleh variabel lain yang tidak diteliti.
\end{abstract}

Kata kunci: Disiplin kerja dan Prestasi Kerja

\section{PENDAHULAN}

Sejalan dengan program pemerintah dalam rangka meningkatkan pembangunan di segala bidang baik pusat maupun daerah, yang mencangkup segala aspek. Untuk melaksanakan kegiatan pembangunan tersebut harus didukung oleh sumber daya manusia. Sumber daya manusia ini diperoleh dari salah satu bidang yang mendapat perhatian serius dari pemerintah yaitu bidang pendidikan. Untuk membantu proses ketersediaan dan peningkatan sumber daya manusia tersebut disiplin yang tinggi adalah merupakan salah satu wadah yang sangat besar peran sertanya. Dalam hal ini perhatian pemerintah terhadap disiplin pegawai ditunjukkan dengan diterbitkan Peraturan Pemerintah Nomor 53 Tahun 2010 tentang Disiplin Pegawai Negeri.

Sebagai bangsa yang mempunyai cita-cita untuk mewujudkan tujuan nasional sebagaimana diamanatkan dalam Pembukaan Undang-Undang Dasar 1945, yaitu masyarakat yang adil makmur dan lestari berdasarkan pancasila, maka diperlukan upaya bertahap, berencana dan berkesinambungan, melalui perjuangan dan pembangunan dengan semangat dan kemauan yang kuat dan pantang mundur.

Dengan pembaharuan yang demikian itu perlu didukung oleh suasana yang sesuai, yaitu berupa tata kehidupan masyarakat yang sehat, tertib dan teratur. Atau dengan kata lain 
diperlukan mentalitas nasional sesuai dengan watak pembangunan, yang arahnya adalah menuju kepada pertumbuhan, perubahan dan kemajuan. Apabila manusia yang menjadi subyek dan sekaligus obyek pembangunan tersebut tidak memiliki mentalitas pembangunan yang sesuai, maka akan sangat mengganggu jalannya pembangunan.

Kondisi obyektif menunjukkan bahwa sikap mental seperti dikehendaki di atas belum sepenuhnya menampakkan diri dan belum dikembangkan secara mendalam dan konsepsional. Setiap masyarakat yang hendak hidup tertib dan teratur memerlukan sikap dan perilaku pada warganya yang berdisiplin. Seorang warga masyarakat yang berdisiplin selalu bersikap dan berperilaku sesuai dengan ketentuan yang dianggap baik oleh masyarakat dan mendukung pembangunan. Dengan ketentuan-ketentuan itu terwujud nilai- nilai serta kaidah- kaidah sosial yang positif, dengan demikian maka dari setiap warga masyarakat diharapkan kesadaran atas kepentingan umum yang diaktualisasikan dengan berperilaku yang tertib dan teratur serta bergairah dalam ikut serta berprestasi aktif dalam pembangunan.

Dalam rangka meningkatkan pelayanan, pengayoman serta menumbuhkan prakarsa dan peran aktif masyarakat dalam penyelenggaraan pemerintahan dan pembangunan perlu dilaksanakan disiplin dalam organisasi terutama instansi pemerintah dalam upaya pencapaian tujuan organisasi dan tujuan pembangunan.

Kedisiplinan ini tidak mudah dan tentu membutuhkan keadaan pribadi dalam menjalankannya sadar akan tanggung jawab untuk menyelenggarakan tugas pemerintahan dan pembangunan. Salah satu cara yang tepat membantu menjamin dalam melakukan pengawasan terhadap disiplin kerja yaitu pelaksanaan pengawasan melekat (waskat), yaitu merupakan pengawasan yang dilakukan oleh setiap pimpinan terhadap bawahannya dan satuan kerja yang dipimpinnya.

Seorang pimpinan organisasi dapat dikatakan berhasil menegakkan disiplin kerja serta memotivasi pegawainya dengan baik, hal ini dapat dilihat melalui kehadirannya dan pelaksanaan apel kerja serta sikap kerja pegawai terhadap pekerjaan yang diembannya yaitu apakah pegawai tersebut dapat bekerja dengan baik dan sungguh-sungguh, bersemangat dan tidak terlihat sikap terpaksa dalam melaksanakan pekerjaannya, jujur serta bertanggung jawab penuh terhadap tugas yang diberikan kepadanya.

Puskesmas Kecamatan Depati VII Kabupaten Kerinci merupakan instansi pemerintah yang dalam pelaksanaannya berdasarkan peraturan-peraturan yang telah ditetapkan oleh pemerintah dan merupakan unsur pelaksana pemerintah Kabupaten dipimpin oleh seorang kepala yang berada dibawah dan bertanggung jawab kepada Dinas Kesehatan Kabupaten Kerinci.

Puskesmas di Kecamatan Depati VII mempunyai tugas melakukan kewenangan otonomi daerah dalam rangka pelaksanaan tugas desentralisasi dalam bidang kesehatan masyarakat. Oleh sebab itu pelaksanaan disiplin dan peningkatan prestasi kerja pegawainya sangatlah diperlukan.

Pimpinan harus mampu melaksanakan disiplin kerja pegawainya, dalam rangka meningkatkan pencapaian hasil pekerjaan dalam pelaksanaan tugas sehari-hari sesuai dengan rencana yang telah ditetapkan semula, guna untuk mencapai sasaran pelaksanaan tugas, agar tercapai tujuan pemerintah dan pembangunan, sehingga terwujud visi dan misi. Dengan meningkatkan kesehatan masyarakat dan kualitas sumber daya manusia baik aparatur pemerintah maupun pelaku pembangunan serta dapat meningkatkan kualitas di bidang pendidikan dan keterampilan.

Pada Puskesmas di Kecamatan Depati VII telah ditetapkan beberapa aturan yang diberlakukan bagi setiap pegawai diantaranya penetapan daftar piket, dan tupoksi masingmasing bagian serta pengambilan absensi atau daftar hadir, berikut akan ditampilkan 
persentase absensi dari 51 orang Pegawai pada Puskesmas di Kecamatan Depati VII pada tahun 2012 seperti yang terdapat dalam tabel 1.1 berikut :

Persentase Absensi Pegawai pada Puskesmas di Kecamatan Depati VII Tahun 2012

\begin{tabular}{|l|l|l|l|l|l|}
\hline \multirow{2}{*}{$\begin{array}{c}\text { NAMA } \\
\text { BULAN }\end{array}$} & $\begin{array}{c}\text { TIDAK } \\
\text { HADIR } \\
\text { (Orang) }\end{array}$ & $\%$ & $\begin{array}{c}\text { TOTAL KEHADIRAN } \\
\text { (Orang) }\end{array}$ & \multirow{2}{*}{ KET } \\
\hline Januari & 20 & 39,21 & 31 & 60,78 & \\
\hline Pebruari & 19 & 37,25 & 32 & 62,74 & \\
\hline Maret & 20 & 39,21 & 31 & 60,78 & \\
\hline April & 18 & 35,26 & 33 & 64,70 & \\
\hline Mei & 17 & 33,33 & 34 & 66,66 & \\
\hline Juni & 19 & 37,25 & 32 & 62,74 & \\
\hline Juli & 18 & 35,26 & 33 & 64,70 & \\
\hline Agustus & 18 & 35,26 & 33 & 64,70 & \\
\hline September & 19 & 37,25 & 32 & 62,74 & \\
\hline Oktober & 17 & 33,33 & 34 & 66,66 & \\
\hline Nopember & 18 & 35,26 & 33 & 64,70 & \\
\hline Desember & 19 & 37,25 & 32 & 62,74 & \\
\hline
\end{tabular}

Sumber : Puskesmas di Kecamatan Depati VII

Secara umum berdasarkan hasil pengamatan awal ditemui beberapa fenomena diantaranya :

1. Kehadiran pegawai pada Puskesmas di Kecamatan Depati VII pada tahun 2012 adalah tidak baik, dalam arti kata sangat kecil jumlah pegawai yang hadir dalam pekerjaan.

2. Ada beberapa pegawai yang datang ke puskesmas selalu terlambat, sehingga pasien puskesmas sudah antri menunggu pada poli tertentu untuk berobat.

3. Sering terjadinya keterlambatan pelayanan yang diberikan, dimana untuk suatu urusan pelayanan yang seharusnyadapat lebih cepat dikerjakan malah harus menunggu petugas yang asik ngobrol dengan rekan pegawainya.

4. Pegawai puskesmas banyak yang pulang lebih cepat dari jadwal yang telah ditetapkan.

Untuk pembahasan masalah yang dihadapi, maka penelitian ini memfokuskan pada pengaruh disiplin terhadap prestasi kerja.

Berdasarkan uraian dan data-data di atas, maka penulis tertarik untuk mengadakan penelitan lebih lanjut yang dituangkan dalam bentuk skripsi dengan judul "Pengaruh Disiplin Kerja Terhadap Prestasi Kerja Pegawai pada Puskesmas di Kecamatan Depati VII Kabupaten Kerinci ".

\section{Disiplin Kerja \\ Pengertian Disiplin}

Kata disiplin itu sendiri berasal dari bahasa Latin "discipline" yang berarti "latihan atau pendidikan kesopanan dan kerohanian serta pengembangan tabiat". Hal ini menekankan pada bantuan kepada pegawai untuk mengembangkan sikap yang layak terhadap pekerjaannya. Disiplin merupakan suatu kekuatan yang berkembang di dalam tubuh pekerja sendiri yang menyebabkan dia dapat menyesuaikan diri dengan sukarela kepada keputusan-keputusan, peraturan-peraturan, dan nilai-nilai tinggi dari pekerjaan dan tingkah laku (Asmiarsih 2006:23).

Menurut David dalam Mangkunegara (2001:129), menyatakan bahwa disiplin kerja dapat diartikan sebagai pelaksanan manajemen untuk memperteguh pedoman-pedoman organisasi. 
Menurut Husnan dalam Budiarti (2002:15) Disiplin adalah setiap perseorangan dan juga kelompok yang menjamin adanya kepatuhan terhadap perintah dan berinisiatif untuk melakukan suatu tindakan yang diperlukan seandainya tidak ada perintah.

Menurut Davis dalam Budiarti (2002:112) Disiplin adalah tindakan manajemen untuk memberikan semangat kepada pelaksanaan standar organisasi, ini adalah pelatihan yang mengarah pada upaya membenarkan dan melibatkan pengetahuan-pengetahuan sikap dan perilaku pegawai sehingga ada kemauan pada diri pegawai untuk menuju pada kerjasama dan prestasi yang lebih baik.

Rumusan lain menyatakan bahwa disiplin merupakan tindakan manajemen mendorong para anggota organisasi memenuhi tuntutan berbagai ketentuan tersebut. Dengan perkataan lain, pendisiplinan pegawai adalah suatu bentuk pelatihan yang berusaha memperbaiki dan membentuk pengetahuan, sikap dan perilaku pegawai sehingga para pegawai tersebut secara sukarela berusaha bekerja secara kooperatif dengan para pegawai yang lain serta meningkatkan prestasi kerjanya (Siagian, 2000: 305). Sedangkan pendapat Sastrohadiwiryo (2003:291) disiplin kerja dapat didefinisikan sabagai suatu sikap menghormati, menghargai, patuh, dan taat terhadap peraturan-peraturan yang berlaku baik yang tertulis maupun tidak tertulis serta sanggup menjalankannya dan tidak mengelak untuk menerima sanksi-sanksinya apabila ia melanggar tugas dan wewenang yang diberikan kepadanya.

Kedisiplinan adalah kesadaran dan kesediaan seseorang menaati semua peraturan instansi dan norma-norma sosial yang berlaku. Kesadaran disini merupakan sikap seseorang yang secara sukarela menaati semua peraturan dan sadar akan tugas dan tanggung jawabnya. Jadi, dia akan mematuhi atau mengerjakan semua tugasnya dengan baik, bukan atas paksaan. Sedangkan kesediaan adalah suatu sikap, tingkah laku, dan perbuatan seseorang yang sesuai dengan peraturan instansi, baik yang tertulis maupun tidak tertulis (Hasibuan, 2005:193-194).

Berdasarkan pendapat-pendapat tersebut, dapat disimpulkan bahwa disiplin kerja pegawai merupakan sikap atau tingkah laku yang menunjukkan kesetiaan dan ketaatan seseorang atau sekelompok orang terhadap peraturan yang telah ditetapkan oleh instansi atau organisasinya baik yang tertulis maupun tidak tertulis sehingga diharapkan pekerjaan yang dilakukan efektif dan efesien.

Saydam (2005:284), Mengatakan bahwa indikator yang mempengaruhi tingkat kedisiplinan adalah:

1. Kehadiran

Kehadiran adalah datangnya pegawai pada instansi dimana dia bekerja. Hadir tepat waktu dan masuk setiap hari adalah tuntutan kepada pegawai.

2. Tanggung Jawab

Pegawai yang bertanggung jawab adalah pegawai yang melaksanakan semua tugas yang diemban kepadanya. Tugas yang diberikan dikerjakan dengan tepat waktu dan menyelesaikan tugas dengan baik.

3. Sikap

Kemampuan berkomunikasi dengan klien adalah suatu sikap positif yang dimiliki oleh pegawai. Dengan menggunakan seragam kantor membuat klien lebih bisa membedakan mana pegawai dan mana klien lainnya. Pegawai juga harus selalu bisa menerima setiap kritik dan saran yang diberikan kepadanya. Pegawai juga harus menunjukkan sikap yang baik dengan cara membantu klien.

4. Norma

Peraturan yang telah dibuat harus disepakai setiap pegawai. Karena mematuhi peraturan akan mempermudah setiap pekerjaan. 


\section{Tujuan Disiplin Kerja}

Secara umum dapat disebutkan bahwa tujuan utama disiplin kerja adalah demi kelangsungan organisasi atau instansi sesuai dengan motif organisasi atau instansi yang bersangkutan baik hari ini maupun hari esok. Menurut Sastrohadiwiryo (2003:292) secara khusus tujuan disiplin kerja para pegawai, antara lain :

1. Agar para pegawai menepati segala peraturan dan kebijakan ketenagakerjaan maupun peraturan dan kebijakan organisasi yang berlaku, baik tertulis maupun tidak tertulis, serta melaksanakan perintah manajemen dengan baik.

2. Pegawai dapat melaksanakan pekerjaan dengan sebaik-baiknya serta mampu memberikan pelayanan yang maksimum kepada pihak tertentu yang berkepentingan dengan organisasi sesuai dengan bidang pekerjaan yang diberikan kepadanya.

3. Pegawai dapat menggunakan dan memelihara sarana dan prasarana, barang dan jasa organisasi dengan sebaik-baiknya.

4. Para pegawai dapat bertindak dan berpartisipasi sesuai dengan norma-norma yang berlaku pada organisasi.

5. Pegawai mampu menghasilkan produktivitas yang tinggi sesuai dengan harapan organisasi, baik dalam jangka pendek maupun jangka panjang.

\section{Jenis-jenis Disiplin Kerja}

Newstrom dalam Asmiarsih (2006) menyatakan bahwa disiplin mempunyai 3 (tiga) macam bentuk, yaitu :

1. Disiplin Preventif

Disiplin preventif adalah tindakan SDM agar terdorong untuk menaati standar atau peraturan. Tujuan pokoknya adalah mendorong SDM agar memiliki disiplin pribadi yang tinggi, agar peran kepemimpinan tidak terlalu berat dengan pengawasan atau pemaksaan, yang dapat mematikan prakarsa dan kreativitas serta partisipasi SDM.

2. Disiplin Korektif

Disiplin korektif adalah tindakan dilakukan setelah terjadi pelanggaran standar atau peraturan, tindakan tersebut dimaksud untuk mencegah timbulnya pelanggaran lebih lanjut. Tindakan itu biasanya berupa hukuman tertentu yang biasa disebut sebagai tindakan disipliner, antara lain berupa peringatan, skors, pemecatan.

3. Disiplin Progesif

Disiplin progresif adalah tindakan disipliner berulang kali berupa hukuman yang makin berat, dengan maksud agar pihak pelanggar bisa memperbaiki diri sebelum hukuman berat dijatuhkan.

\section{Faktor-Faktor Yang Mempengaruhi Tingkat Kedisiplinan}

Menurut Hasibuan (2005:194-198) faktor-faktor yang mempengaruhi kedisiplinan adalah sebagai berikut:

1. Tujuan dan kemampuan

Tujuan dan kemampuan ini mempengaruhi tingkat kedisiplinan pegawai. Tujuan yang akan dicapai harus jelas dan ditetapkan secara ideal serta cukup menantang bagi kemampuan pegawai. Hal ini berarti bahwa pekerjaan yang dibebankan kepada pegawai harus sesuai dengan kemampuan pegawai bersangkutan agar pegawai tersebut bekerja dengan sungguhsungguh.

2. Teladan pimpinan

Dengan teladan pimpinan yang baik, kedisiplinan bawahan akan ikut baik.

\section{Balas Jasa}


Balas jasa atau gaji, kesejahteraan ikut mempengaruhi kedisiplinan pegawai, karena balas jasa akan memberikan kepuasan dan kecintaan pegawai terhadap instansi. Jika kecintaan pegawai semakin tinggi terhadap pekerjaan kedisiplinan akan semakin baik. Untuk mewujudkan kedisiplinan pegawai yang baik instansi harus memberikan balas jasa yang relatif besar.

4. Keadilan

Keadilan yang dijadikan dasar kebijakan dalam pemberian balas jasa atau hukuman akan tercipta kedisiplinan yang baik. Pemimpin yang baik dalam memimpin selalu berusaha bersikap adil terhadap semua pegawai. Dengan keadilan yang baik akan menciptakan kedisiplinan yang baik pula.

5. Waskat (pengawasan melekat)

Waskat adalah tindakan nyata paling efektif dalam mewujudkan kedisiplinan pegawai instansi. Dengan waskat berarti atasan harus aktif dan langsung mengatasi perilaku, moral, sikap, gairah kerja dan prestasi kerja bawahannya.

6. Sanksi hukuman

Sanksi hukuman berperan penting dalam memelihara kedisiplinan pegawai. Dengan sanksi hukuman yang semakin berat, pegawai akan semakin takut melanggar peraturanperaturan instansi. Berat atau ringan sanksi hukuman yang akan diterapkan ikut mempengaruhi baik buruknya kedisiplinan pegawai.

7. Ketegasan

Ketegasan pimpinan dalam melakukan tindakan akan mempengaruhi kedisiplinan pegawai instansi, pimpinan harus berani dan tegas bertindak untuk memberikan sanksi sesuai dengan yang telah ditetapkan instansi sebelumnya. Dengan demikian pimpinan akan dapat memelihara kedisiplinan pegawai instansi.

8. Hubungan kemanusiaan

Hubungan kemanusiaan yang harmonis diantara sesama pegawai ikut menciptakan kedisiplinan yang baik pada suatu instansi. Pemimpin harus berusaha menciptakan suasana hubungan kemanusiaan yang serasi baik diantara semua pegawai. Kedisiplinan pegawai akan tercipta apabila hubungan kemanusiaan dalam organisasi tersebut baik.

\section{Prinsip-prinsip Pendisiplinan} (2006) adalah :

Prinsip-prinsip pendisiplinan yang dikemukakan Ranupandojo dalam Asmiarsih

a. Pendisiplinan dilakukan secara pribadi

Pendisiplinan seharusnya dilakukan dengan memberikan teguran kepada pegawai. Teguran jangan dilakukan di hadapan orang banyak. Karena dapat menyebabkan pegawai yang ditegur akan merasa malu dan tidak menutup kemungkinan menimbulkan rasa dendam yang dapat merugikan organisasi.

b. Pendisiplinan harus bersifat membangun.

Selain memberikan teguran dan menunjukkan kesalahan yang dilakukan pegawai, harus disertai dengan saran tentang bagaimana seharusnya berbuat untuk tidak mengulangi lagi kesalahan yang sama.

c. Pendisiplinan harus dilakukan sacara langsung dengan segera.

Suatu tindakan dilakukan dengan segera setelah terbukti bahwa pegawai telah melakukan kesalahan. Jangan membiarkan masalah menjadi kadaluarsa sehingga terlupakan oleh pegawai yang bersangkutan.

d. Keadilan dalam pendisiplinan sangat diperlukan. 
Dalam tindakan pendisiplinan dilakukan secara adil tanpa pilih kasih. Siapapun yang telah melakukan kesalahan harus mendapat tindakan pendisiplinan secara adil tanpa membedabedakan.

e. Pimpinan hendaknya tidak melakukan pendisiplinan sewaktu pegawai absen.

Pendisiplinan hendaknya dilakukan dihadapan pegawai yang bersangkutan secara pribadi agar ia tahu telah melakukan kesalahan. Karena akan percuma pendisiplinan yang dilakukan tanpa adanya pihak yang bersangkutan.

f. Setelah pendisiplinan sikap dari pimpinan haruslah wajar kembali.

Sikap wajar hendaknya dilakukan pimpinan terhadap pegawai yang telah melakukan kesalahan tersebut. Dengan demikian, proses kerja dapat lancar kembali dan tidak kaku dalam bersikap.

\section{Tingkat dan Jenis Sanksi Disiplin Kerja}

Tujuan utama pengadaan sanksi disiplin kerja bagi para tenaga kerja yang melanggar norma-norma organisasi adalah memperbaiki dan mendidik para tenaga kerja yang melakukan pelanggaran disiplin. Pada umumnya sebagai pegangan pimpinan meskipun tidak mutlak, tingkat dan jenis sanksi disiplin kerja yang dikemukakan di tuangkan di Peraturan Pemerintah Nomor 53 Tahun 2010 terdiri atas sanksi disiplin ringan, sanksi disiplin sedang, sanksi disiplin berat.

1. Jenis hukuman disiplin ringan

a. Teguran lisan;

b. Teguran tertulis; dan

c. Pernyataan tidak puas secara tertulis.

2. Jenis hukuman disiplin sedang

a. Penundaan kenaikan gaji berkala selama 1 (satu) tahun;

b. Penundaan kenaikan pangkat selama 1 (satu) tahun; dan

c. Penurunan pangkat setingkat lebih rendah selama 1 (satu) tahun.

3. Jenis hukuman disiplin berat

a. Penurunan pangkat setingkat lebih rendah selama 3 (tiga) tahun;

b. Pemindahan dalam rangka penurunan jabatan setingkat lebih rendah;

c. Pembebasan dari jabatan;

d. Pemberhentian dengan hormat tidak atas permintaan sendiri sebagai PNS;

e. Pemberhentian tidak dengan hormat sebagai PNS.

Instansi dalam penetapan jenis sanksi disiplin yang akan dijatuhkan kepada pegawai yang melanggar hendaknya dipertimbangkan dengan cermat, teliti, dan seksama bahwa sanksi disiplin yang akan dijatuhkan tersebut setimpal dengan tindakan dan perilaku yang diperbuat. Dengan demikian, sanksi disiplin tersebut dapat diterima dengan rasa keadilan. Kepada pegawai yang pernah diberikan sanksi disiplin dan mengulangi lagi pada kasus yang sama, perlu dijatuhi sanksi disiplin yang lebih berat dengan tetap berpedoman pada kebijakan pemerintah yang berlaku.

\section{Prestasi Kerja \\ Pengertian Prestasi Kerja}

Mangkunegara (2001:67) mendefenisikan prestasi kerja adalah hasil kerja secara kualitas dan kuantitas yang dicapai oleh seorang pegawai dalam melaksanakan tugasnya sesuai dengan tanggung jawab yang diberikan kepadanya. 
Menurut Soeprihanto (2001:7) prestasi kerja adalah hasil kerja seorang pegawai selama periode tertentu dibandingkan dengan berbagai kemungkinan misalnya standar, target, sasaran atau kriteria yang telah ditentukan terlebih dahulu dan telah disepakati bersama.

\section{Penilaian Prestasi Kerja}

Menurut Panggabean (2004:72) penilaian prestasi kerja adalah suatu proses yang bertujuan untuk mengetahui atau memahami tingkat kinerja pegawai dibandingkan dengan tingkat kinerja pegawai lainnya atau dibandingkan dengan standart yang telah ditetapkan.

Menurut Soeprihanto (2001:7) penilaian prestasi kerja adalah suatu sistem yang digunakan untuk menilai dan mengetahui apakah seorang pegawai telah melaksanakan pekerjaannya masing-masing secara keseluruhan.

Berdasarkan definisi terdahulu dapat disimpulkan bahwa penilaian prestasi kerja pegawai merupakan suatu proses yang digunakan untuk mengevaluasi kemampuan kerja para pegawai dengan cara yang subjektif mungkin serta menggunakan standrat kerja yang telah ditetapkan.

\section{Faktor-Faktor Yang Mempengaruhi Prestasi Kerja Pegawai}

Menurut Sulistiyani (2003:200) faktor-faktor yang mempengaruhi prestasi kerja pegawai yaitu:

1. Pengetahuan

Kemampuan yang dimiliki pegawai yang lebih berorientasi pada intelejensi dan daya pikir serta penguasaan ilmu yang lebih luas yang dimiliki pegawai.

2. Keterampilan pegawai.

Kemampuan dan penguasaan teknis operasional yang dibidang tertentu yang dimiliki

\section{Kemampuan}

Kemampuan yang terbentuk dari sejumlah kompetensi yang dimiliki oleh seorang pegawai.

4. Sikap yaitu suatu kebiasaan yang terpolakan.

5. Tingkah Laku kerja.

Perilaku kerja seorang pegawai dalam melaksanakan berbagai kegiatan atau aktivitas

\section{Tujuan Penilaian Prestasi Kerja Pegawai}

Penilaian prestasi kerja pegawai berguna untuk instansi serta bermanfaat bagi pegawai. Menurut Hasibuan (2005:89-90) tujuan penilaian prestasi kerja pegawai sebagai berikut:
a. Sebagai dasar dalam pengambilan keputusan yang digunakan untuk promosi, demosi, pemberhentian dan penetapan besarnya balas jasa.
b. Untuk mengukur prestasi pegawai yaitu sejauh mana pegawai bisa sukses dalam pekerjaannya.
c. Sebagai dasar untuk mengevaluasi efektivitas seluruh kegiatan di dalam instansi.
d. Sebagai dasar untuk mengevaluasi program latihan dan keefektifan jadwal kerja, metode kerja, struktur organisasi, gaya pengawasan, kondisi kerja.
e. Sebagai indikator untuk menentukan kebutuhan akan latihan bagi pegawai yang berada di dalam organisasi.
f. Sebagai alat untuk meningkatkan motivasi kerja pegawai sehingga dicapai tujuan untuk mendapatkan performance kerja yang baik.


g. Sebagai alat untuk mendorong atau membiasakan para atasan untuk mengobservasi perilaku bawahan supaya diketahui minat dan kebutuhan-kebutuhan bawahannya.

h. Sebagai alat untuk bisa melihat kekurangan atau kelemahan-kelemahan di masa lampau dan meningkatkan kemampuan pegawai selanjutnya.

i. Sebagai kriteria di dalam menentukan seleksi dan penempatan pegawai.

j. Sebagai alat mengidentifikasi kelemahan-kelemahan personel dan dengan demikian bisa sebagai bahan pertimbangan agar bisa diikutsertakan dalam program latihan kerja tambahan.

k. Sebagai alat untuk memperbaiki atau mengembangkan kecakapan pegawai.

1. Sebagai dasar untuk memperbaiki dan mengembangkan uraian pekerjaan.

Rivai (2004:443) mengatakan bahwa indikator yang mempengaruhi prestasi kerja adalah kemampuan.

\section{Metode Penilaian Prestai Kerja}

Menurut Handoko (2000:142) metode dalam penilaian prestasi kerja pegawai, yaitu:

\section{Rating Scale}

a. Metode Penilaian Berorientasi Masa Lalu

Pada metode ini evaluasi dilakukan oleh penilai terhadap prestasi kerja pegawai dengan skala tertentu dari rendah sampai tinggi. Evaluasi hanya didasarkan pada pendapat penilai, yang membandingkan hasil pekerjaan pegawai dengan faktor-faktor (kriteria) yang dianggap penting bagi pelaksanaan pekerjaan tersebut.

\section{Checklist}

Metode penilaian ini dimaksudkan untuk mengukur beberapa penilai. Penilai tinggal memilih kalimat-kalimat atau kata-kata yang menggambarkan prestasi kerja dan karakteristikkarakteristik pegawai. Metode ini dapat memberikan suatu gambaran prestasi kerja secara akurat, bila daftar penilaian berisi item-item yang memadai.

\section{Metode Peristiwa Kritis}

Merupakan metode penilaian yang mendasarkan pada catatan-catatan penilai yang menggambarkan perilaku pegawai sangat baik atau sangat jelek dalam kaitannya dengan pelaksanaan kerja.

4. Peninjauan Lapangan

Agar tercapai penilaian yang lebih terstandardisasi, banyak instansi menggunakan metode peninjauan lapangan. Dengan metode ini wakil ahli departemen personalia turun ke lapangan dan membantu para penyelia dalam penilaian mereka.

5. Tes Dan Observasi Prestasi Kerja

Bila jumlah pekerja terbatas penilaian prestasi kerja bisa dilakukan pada tes pengetahuan dan keterampilan.

6. Metode Evaluasi Kelompok

Metode penilaian kelompok berguna untuk pengambilan keputusan kenaikan upah, promosi dan berbagai bentuk penghargaan organisasi karena dapat menghasilkan ranking pegawai dari yang terbaik sampai terjelek.

\section{Penilaian Diri}

\section{b. Metode Penilaian Berorientasi Masa Depan}

Teknik evaluasi ini berguna bila tujuan evaluasi adalah untuk melanjutkan pengembangan diri.

\section{Penilaian Psikologis}

Penilaian ini terdiri dari wawancara mendalam, tes-tes psikologi, diskusi dengan atasan langsung. Penilaian ini dilakukan oleh para psikolog untuk menilai potensi pegawai di waktu 
yang akan datang. Evaluasi terhadap intelektual, emosi, motivasi pegawai dan karakteristik lainnya diharapkan bisa membantu untuk memperkirakan prestasi kerja diwaktu yang akan datang.

3. Pendekatan Management By Objectives (MBO)

Inti pendekatan $\mathrm{MBO}$ adalah setiap pegawai dan penyelia secara bersama menetapkan tujuan-tujuan atau sasaran-sasaran pelaksanaan kerja diwaktu yang akan datang.

\section{METODE PENELITIAN}

\section{Pendekatan Penelitian}

Penelitian yang baik adalah penelitian yang dilakukan secara terfokus dan mendalam. Agar penelitian data dilakukan secara terfokus maka tidak semua masalah diteliti. Penelitian ini hanya dibatasi mengenai pengaruh disiplin kerja terhadap prestasi kerja pegawai dengan responden penelitian adalah pegawai Puskesmas di Kecamatan Depati VII. Pendekatan yang digunakan adalah pendekatan kuantitatif. Yaitu menggunakan alat untuk menganalisis dengan melakukan perhitungan pengaruh disiplin kerja terhadap prestasi kerja pegawai pada Puskesmas di Kecamatan Depati VII.

\section{Populasi dan Sampel} Populasi

Populasi adalah daerah generalisasi yang akan dikenai kesimpulan hasil penelitian (Hadi, 2006;70), mengatakan bahwa populasi merupakan sejumlah individu yang setidaknya mempunyai satu ciri atau sifat yang sama. Dari polulasi ini diambil contoh atau sampel yang diharapkan dapat mewakili populasi serta memberikan batas - batas yang jelas. Dalam penelitian ini populasi yang diambil adalah seluruh pegawai Puskesmas di Kecamatan Depati VII yang berjumlah 51 orang.

\section{Sampel}

Menurut Arikunto (1997:109) Sampel adalah sebagai wakil populasi yang diteliti dalam menentukan beberapa jumlah sampel yang harus diambil, penulis menggunakan pendapat Arikunto yaitu, jumlah polulasi yang kurang dari 100 maka jumlah polulasi tersebut dapat diambillangsung semuanya untuk dijadikan sampel.

Mengacu pada pendapat diatas maka dalam penelitian ini digunakan teknik pengambilan populasi sebagai sampel, hal ini disebabkan karena jumlah pegawai pada Puskesmas di Kecamatan Depati VII kurang dari 100 yaitu 51 orang.

\section{Responden}

Responden adalah objek penelitian yang akan dimintai data atau menjawab pertanyaan dalam quesioner yang diberikan. Responden merupakan sampel yang telah ditetapkan jumlahnya. Namun demikian responden dapat digunakan untuk melengkapi keterangan yang memang diperlukan. Dalam hal ini, responden yang di berlakukan adalah sampel yang telah ditetapkan dari populasi yang ada di Puskesmas di Kecamatan Depati VII. Daftar nama responden tercantum dalam tabel sebagai berikut.

Daftar Pegawai pada Puskesmas di Kecamatan Depati VII

\begin{tabular}{|c|l|l|}
\hline No & Populasi & Jumlah \\
\hline 1 & Kepala Puskesmas & 1 Orang \\
\hline 2 & Poli Umum & 5 Orang \\
\hline 3 & Poli Gigi & 6 Orang \\
\hline 4 & Tata Usaha & 4 Orang \\
\hline 5 & Poli Lansia & 4 Orang \\
\hline
\end{tabular}




\begin{tabular}{|c|l|l|}
\hline 6 & Poli UP2K & 4 Orang \\
\hline 7 & Laboratorium & 2 Orang \\
\hline 8 & Karcis & 3 Orang \\
\hline 9 & Kebidanan & 19 Orang \\
\hline 10 & Apotik Jumlah & 3 Orang \\
\hline \multicolumn{2}{|c|}{} & 51 Orang \\
\hline
\end{tabular}

Sumber : Puskesmas di Kecamatan Depati VII

\section{Tekhnik dan alat pengumpulan data yang digunakan}

Dalam pengumpulan data dan penulisan Skripsi ini peneliti menggunakan beberapa metode diantaranya :

1. Penelitian Kepustakaan ( Library Research)

Pengumpulan data yang berupa teori-teori, dan konsep-konsep yang penting dan mempunyai relevansi dengan masalah pokok penelitian ini, dilakukan dengan menelaah berbagai literautur-literatul dan buku-buku ilmiah yang ada kaitannya dengan masalah yang diteliti terutama masalah yang berhubungan dengan pengaruh disiplin kerja terhadap prestasi kerja pada Puskesmas di Kecamatan Depati VII.

2. Penelitian Lapangan ( Field Research)

Pengumpulan data yang langsung kepada sumber penelitian dilapangan, dilakukan dengan cara :

a. Wawancara

Yaitu meminta keterangan secara langsung perihal yang ada hubungannya dengan penelitian melalui sumber data.

b. Angket ( Questioner)

Yaitu menyebarkan daftar pertanyaan ( questioner), yang diberikan kepada responden yang selanjutnya digunakan dalam proses analisa data untuk menemukan jawaban permasalah pokok dalam penelitian ini.

Jenis data yang digunakan dalam penelitian ini adalah berupa data primer, yaitu data yang dikumpulkan dengan survey langsung ke objek penelitian melalui pendekatan Quesioner sesuai dengan daftar pertanyaan yang disipkan. Dan data sekunder, yaitu data pendukung yaitu diperoleh dari objek penelitian.

\section{Interprestasi Data}

Untuk menganalisis pengaruh disipin kerja terhadap prestasi kerja pegawai pada Puskesmas di Kecamatan Depati VII, yang penulis gunakan dalam penelitian ini menurut Bagong Suyanto (2005:134) adalah dengan cara kuantitatif yaitu menganalisa data berdasarkan teori-teori yang ada hubungannya dengan permasalahan yang diteliti dengan menggunakan angka-angka, rumus-rumus dan presentase dari jawaban responden.

\section{Alat Analisis}

Dalam menganalisa digunakan beberapa alat yaitu :

\section{a. Skala Liker}

Setelah data dan informasi dikumpulkan dan diolah, data tersebut dimasukkan ke dalam skala liker, yang ma amenurut sugiono (2003:107) Skala liker digunakan untuk mengukur sikap, pendapat dan persepsi seseorang atau sekelompok orang tertentu kejadian atau gejala sosial. Dari data kualitatif yang diperoleh dijadikan data kuantitatif dengan memberikan skor nilai terhadap setiap pertanyaan quesiotner yang diberikan. Selanjutnya dari jawaban quetsioner yang diberikan kepada responden, dilakukan pembobotan untukmenilai secara kuantitatif terhadap jawaban responden 
tentang peranan disiplin kerja terhadap prestasi kerja pegawai pada Puskesmas di Kecamatan Depati VII.

Setelah dilakukan rekapitulasi dari seluruh nilai yang diperoleh dari jawaban responden, maka langkah selanjutnya adalah mengklasifikasikan kriteria penilaian terhadap jawaban responden dengan katgoripenilaian sebagai berikut :

$\begin{array}{ll}\text { Sangat Setuju } & \text { dengan skor 5 } \\ \text { Setuju } & \text { dengan skor 4 } \\ \text { Kurang setuju } & \text { dengan skor 3 } \\ \text { Tidak Setuju } & \text { dengan skor 2 } \\ \text { Sangat tidak setuju } & \text { dengan skor 1 }\end{array}$

\section{b. Koefisiensi Korelasi Person Product Moment}

Menurut Riduan (2004) untuk melihat pengaruh disiplin terhadap prestasi kerja pegawai maka digunakan rumus korelasi Product moment sebagai beikut :

Keterangan

$$
r x y=\frac{n\left(\sum x y\right)-\left(\sum x\right)\left(\sum y\right)}{\sqrt{\left\{n \cdot \sum x^{2}-\left(\sum x\right)^{2}\right\}\left\{n \sum y^{2}-\left(\sum y\right)^{2}\right\}}}
$$

$$
\begin{array}{ll}
r x y & =\text { Korelasi Product Moment } \\
x & =\text { Pariabel bebas (Disiplin Kerja) } \\
y & =\text { Pariabel terikat (Prestasi Kerja) } \\
n & =\text { Jumlah Sampel }
\end{array}
$$

Setelah diketahui koefisiensi korelasinya, maka sebagai pedoman untuk mengetahui apakah terdapat pengaruh antar variabel maka digunakan pedoman yang dapat dilihat pada tabel 1.3 sebagai berikut:

\section{Tabel 1.3}

\section{Pedoman untuk memberikan Interpretasi Koefisien Korelasi}

\begin{tabular}{|l|l|}
\hline Interval Koefisiensi & Tingkat Hubungan \\
\hline $\mathbf{1}$ & $\mathbf{2}$ \\
\hline $0,000-0,199$ & Sangat Tidak Kuat \\
$0,200-0,399$ & Tidak Kuat \\
$0,400-0,599$ & Kurang Kuat \\
$0,600-0,799$ & Kuat \\
$0,800-1,000$ & Sangat Kuat \\
\hline
\end{tabular}

Sumber : Sugiyono (2003:214)

\section{c. Koefisiensi Determinasi (KD)}

Untuk menyatakan besar kecilnya sumbangan variabel $\mathrm{x}$ terhadap variabel $\mathrm{y}$ digunakan rumus Koefisiensi Determinasi sebagai berikut :

$\mathrm{KD}=\mathrm{rxy}^{2} \times 100 \%$

Dimana :

KD = Koefisiensi Determinasi

rxy $\quad=$ Koefisiensi Korelasi

\section{Hipotesis}

Ho $: r=0$ diduga tidak terdapat pengaruh yang signifikan antara disiplin dan prestasi kerja Pegawai pada Puskesmas di Kecamatan Depati VII.

$\mathrm{Ha}: \mathrm{r}=/ 0$ diduga terdapat pengaruh yang signifikan antara disiplin dan prestasi kerja Pegawai pada Puskesmas di Kecamatan Depati VII. 


\section{Uji Hipotesis}

Untuk menguji hipotesis yang diajukan maka dilakukan perhitungan thitung dengan ketentuan tingkat kesalahan $=0,05$ yang selanjutnya dibandingkan dengan ttabel dengan rumus sebagai berikut :

$$
t \text { hitung }=\frac{r \sqrt{ } n-2}{\sqrt{1-r^{2}}}
$$

Keter:

thitung = Nilai $\mathrm{t}$

$\mathrm{r} \quad \quad=$ Nilai Koefisiensi Korelasi

$\mathrm{n} \quad=$ Jumlah Sampel

Kemudian untuk mencari nilai ttabel digunakan tabel distribusi kemudian dilakukan perhitungan dengan menggunakan rumus sebagai berikut :

ttabel $\quad=\mathrm{dk}=\mathrm{n}-2$

Jika thitung lebih besar dari pada ttabel maka Ho ditolak dan Ha diterima, artinya terdapat pengaruh yang signifikan antara disiplin kerja dengan prestasi kerja pegawai pada Puskesmas di Kecamatan Depati VII.

Jika thitung lebih kecil dari pada ttabel maka Ho diterima dan Ha ditolak, artinya tidak terdapat pengaruh yang signifikan antara disiplin kerja dengan prestasi kerja pegawai pada Puskesmas di Kecamatan Depati VII.

Berikut dapat dilihat gambar 1.2. gambar hipotesis.

\section{Gambar Hipotesis}

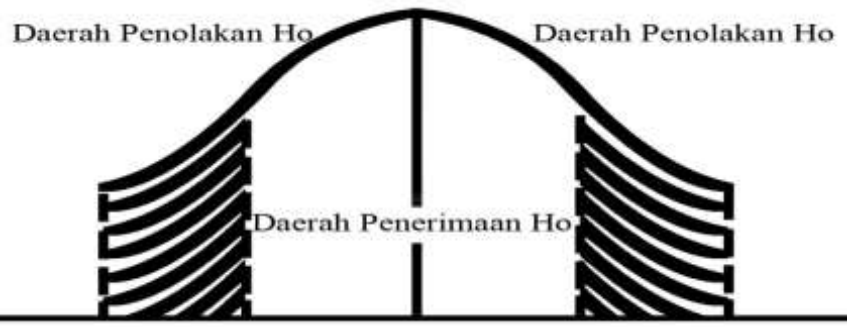

Sumber : Dr. Sugiyono $(2004 ; 215)$

\section{Lokasi Penelitian}

Penelitian dilaksanakan di Puskesmas di Kecamatan Depati VII Kabupaten kerinci. Dengan alasan karena peneliti berasal dari satu kecamatan dengan instansi yang menjadi tempat penelitian. Selain itu agar biaya untuk penelitian juga tidak terlalu mahal karena lokasi penelitian mudah di jangkau dan mudah untuk dikunjungi untuk keperluan penelitian.

\section{Jadwal Penelitian}

Adapun jadwa dalam melaksanakan penelitian adalah sebagai berikut:

\section{Tabel 1.4}

\section{Jadwal Penelitian}

\begin{tabular}{|l|l|l|l|l|l|l|l|l|l|}
\hline \multirow{2}{*}{ No } & \multirow{2}{*}{ Uraian } & \multicolumn{3}{|l|}{ Bulan Mei } & \multicolumn{3}{|l|}{ Bulan Juni } \\
\cline { 3 - 9 } & & I & II & III & IV & I & II & III & IV \\
\hline 1 & Pengajuan Judul & $\sqrt{ }$ & & & & & & & \\
2 & Penyusunan Proposal & & $\sqrt{ }$ & $\sqrt{ }$ & & & & & \\
3 & Penyebaran Kuesioner & & $\sqrt{ }$ & $\sqrt{ }$ & & & & & \\
4 & Seminar Proposal & & & & $\sqrt{ }$ & & & & \\
5 & Mengolah Data Kuesioner & & & & $\sqrt{ }$ & $\sqrt{ }$ & $\sqrt{ }$ & & \\
6 & Penyusunan Skripsi & & & & $\sqrt{ }$ & $\sqrt{ }$ & $\sqrt{ }$ & $\sqrt{ }$ & \\
7 & Ujian Skripsi & & & & & & & & $\sqrt{ }$ \\
\hline
\end{tabular}




\section{HASIL DAN PEMBAHASAN}

\section{Operasional Variabel}

Agar tidak terjadi kesimpang siuran tentang pengertian kedua Variabel yaitu Variabel bebas (x) dan variabel terikat (y), maka perlu didefenisikan variabel bebas dan variabel terikat, sehingga memudahkan dalam menetapkan indikator, instrument dan data, adapun jumlah pegawai pada Puskesmas di kecamatan Depati VII Kabupaten Kerinci adalah sebanyak 51 orang.

\section{Variabel Disiplin kerja (x)}

Menurut David dalam Mangkunegara (2001:129), menyatakan bahwa disiplin kerja dapat diartikan sebagai pelaksanan manajemen untuk memperteguh pedoman-pedoman organisasi. Saydam (2005:284), Mengatakan bahwa indikator yang mempengaruhi tingkat kedisiplinan adalah:

5. Kehadiran

6. Tanggung Jawab

7. Sikap

8. Norma

\section{Variabel Prestasi Kerja (y)}

Mangkunegara (2001:67) mendefenisikan prestasi kerja adalah hasil kerja secara kualitas dan kuantitas yang dicapai oleh seorang pegawai dalam melaksanakan tugasnya sesuai dengan tanggung jawab yang diberikan kepadanya. Menurut Sulistiyani (2003:200) faktorfaktor yang mempengaruhi prestasi kerja pegawai yaitu:
1. Pengetahuan
2. Keterampilan
3. Kemampuan
4. Sikap
5. Tingkah Laku

\section{Hasil Analisis dan Pembahasan}

Pengaruh Didiplin Kerja Terhadap Prestasi Kerja Pegawai di Puskesmas Kecamatan Depati VII

Alat analisis yang digunakan dalam penelitian ini adalah :

\section{Analisis Korelasi Person Produk Momen}

Analisis Korelasi digunakan untuk mengetahui tingkat kekuatan pengaruh disiplin kerja terhadap prestasi kerja pegawai pada puskesmas di kecamatan Depati VII Kabupaten Kerinci dengan rumus sebagai berikut :

$$
r x y=\frac{n\left(\sum x y\right)-\left(\sum x\right)\left(\sum y\right)}{\sqrt{\left\{n \cdot \sum x^{2}-\left(\sum x\right)^{2}\right\}\left\{n \sum y^{2}-\left(\sum y\right)^{2}\right\}}}
$$

Maka nilai $\mathrm{r}$ dapat dicari sebagai berikut :

$$
\begin{aligned}
& r x y=\frac{51(118131)-(2446) \cdot(2461)}{\left.\sqrt{\left\{51 .(117530)-(2446)^{2}\right\} \cdot\left\{51 .(119170)-(2461)^{2}\right.}\right\}} \\
& r x y=\frac{(6024681)-(6019606)}{\sqrt{(5994030)-(5982916) \cdot(6077670)-(6056521)}} \\
& r x y=\frac{(5075)}{\sqrt{(11114) \cdot(21149)}}
\end{aligned}
$$




$$
\begin{aligned}
& r x y=\frac{5075}{\sqrt{235049986}} \\
& r x y=\frac{5075}{15331,3} \\
& \text { 0,33102 Dibulatkan menjadi 0,33 }
\end{aligned}
$$

Berdas: $\quad r x y=$ perhitungan melalui korelasi person tersebut diatas diperoleh nilai $\mathrm{r}$

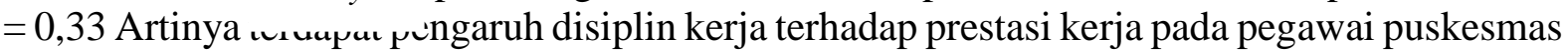
kecamatan Depati VII.

\section{Koefisiensi Determinasi}

Untuk mengetahui seberapa besar Variabel Independent mempengaruhi variabel dependent, maka dilakukan perhitungan koefisien determinasi yaitu sebagai berikut :

$$
\begin{aligned}
& \mathrm{Kd}=\mathrm{rxy}^{2} \times 100 \% \\
& \mathrm{Kd}=0,33^{2} \times 100 \% \\
& \mathrm{Kd}=10,89 \%
\end{aligned}
$$

Koefisiensi determinasi dalam hal ini adalah 10,89 \% artinya presentase Pengaruh disiplin kerja terhadap prestasi kerja pegawai pada puskesmas kecamatan depati VII adalah sebesar $10,89 \%$, sedangkan sisanya $89,11 \%$ ditentukan oleh variabel lain yang tidak dibahas dalam skripsi ini.

\section{Pengujian Hipotesis}

Pengujian lanjutan yaitu uji signifikan yang berfungsi apabila mencari makna pengaruh variabel $\mathrm{x}$ terhadap variabel y maka dilakukan pengujian dengan membandingkan nilai $\mathrm{t}$ hitung dengan $t$ tabel, untuk $t$ hitung rumus yang digunakan :

$$
\mathrm{t} \text { hitung }=\frac{\mathrm{r} \sqrt{\mathrm{n}-2}}{\sqrt{1-\mathrm{r}^{2}}}
$$

Kriteria pengujian apakah hipotesis tersebut ditolak atau diterima adalah sebagai berikut :

1. Jika $\mathrm{t}$ hitung $>\mathrm{t}$ tabel maka Ho ditolak Ha diterima hal ini berarti terdapat pengaruh yang signifikan antara disiplin kerja terhadap prestasi kerja pegawai pada puskesmas di Kecamatan Depati VII Kabupaten kerinci.

2. Jika $\mathrm{t}$ hitung $<\mathrm{t}$ tabel maka Ha ditolak Ho diterima berarti tidak terdapat pengaruh yang signifikan antara disiplin kerja terhadap prestasi kerja pegawai pada puskesmas di Kecamatan Depati VII Kabupaten kerinci.

Maka nilai t hitung dapat dicari sebagai berikut :

$$
\begin{aligned}
& \mathrm{t} \text { hitung }=\frac{\mathrm{r} \sqrt{\mathrm{n}-2}}{\sqrt{1-\mathrm{r}^{2}}} \\
& \mathrm{t} \text { hitung }=\frac{0,33 \sqrt{51}-2}{\sqrt{1-(0,33})^{2}} \\
& \mathrm{t} \text { hitung }=\frac{0,33 \sqrt{49}}{\sqrt{1-0,1089}} \\
& \mathrm{t} \text { hitung }=\frac{0,33 \times 7}{\sqrt{0,8911}} \\
& \mathrm{t} \text { hitung }=\frac{2,31}{0,9440} \\
& \mathrm{t} \text { hitung }=2,4470
\end{aligned}
$$

Kaidah dal $\mathrm{n}$ : 
Berdasarkan perhitungan diatas diketahui t hitung $=2,4470$ sedangkan $t$ tabel dengan ketentuan tingkat kesalahan $=0,05$ dan $\mathrm{n}=51$, dengan uji 2 pihak :

$$
\begin{aligned}
\mathrm{Dk} & =\mathrm{n}-2 \\
& =51-2 \\
& =49
\end{aligned}
$$

Jadi nilai $\mathrm{dk}=\mathrm{n}-2=51-2=49$, untuk $\mathrm{t}$ tabel sebesar $=2,021$

Didapat $\mathrm{t}$ tabel $=2,021$ maka dalam hal ini $\mathrm{t}$ hitung $>\mathrm{t}$ tabel $(2,4470>2,021)$ yang berarti terdapat pengaruh yang signifikan antara disiplin kerja terhadap prestasi kerja pada pegawai puskesmas kecamatan depati VII.

Dalam kurva normal dapat digambarkan sebagai berikut :

\section{Gambar 3.1}

\section{Daerah Penerimaan Hipotesis}

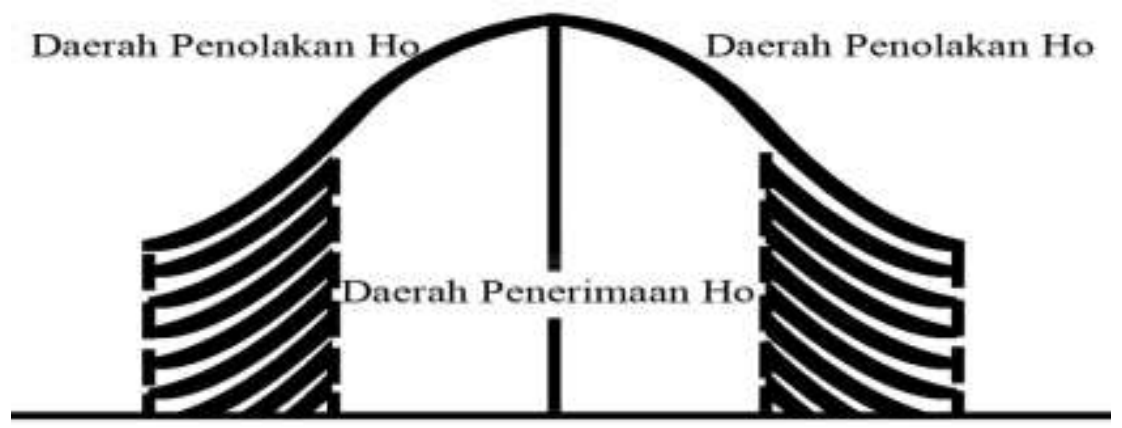

Pada gambar diatas terlihat daerah penerimaan Ho dimana $\mathrm{t}$ hitung $>\mathrm{t}$ tabel $(2,4470>2,021)$ Adanya dua angka yang bernilai positif dan negatif dimaksud bahwa pengujian ini adalah pengujian 2 arah, karena pada hipotesis penulis tidak menetapkan nilai yang positif pada pengaruh antara variabel x dan y, sehingga nilai keduanya sama-sama ditampilkan.

\section{SIMPULAN}

\section{Kesimpulan}

Berdasarkan hasil penelitian tentang pengaruh disiplin kerja terhadap prestasi kerja pegawai pada Puskesmas Kecamatan Depati VII Kabupaten Kerinci maka dapat disimpulkan :

1. Terdapat pengaruh disiplin kerja terhadap prestasi kerja pegawai pada Puskesmas Kecamatan Depati VII Kabupaten Kerinci yang ditunjukkan dengan nilai korelasi sebesar 0,33, artinya pengaruh disiplin kerja terhadap prestasi kerja pegawai pada Puskesmas Kecamatan Depati VII Kabupaten Kerinci tidak kuat.

2. Koefisiensi Determinasi dari data pengaruh disiplin kerja terhadap prestasi kerja pegawai pada Puskesmas Kecamatan Depati VII Kabupaten Kerinci menunjukkan nilai sebesar $10,89 \%$, artinya pengaruh disiplin kerja terhadap prestasi kerja pegawai pada Puskesmas Kecamatan Depati VII Kabupaten Kerinci sebesar 10,89\% sedangkan sisanya 89,11\% dijelaskan oleh sebab-sebab lain yang tidak dibahas pada penelitian ini.

3. Hipotesa penelitian yang diajukan dalam penelitian ini dan terbukti yaitu terdapat pengaruh yang signifikan antara disiplin kerja terhadap prestasi kerja pegawai pada Puskesmas Kecamatan Depati VII Kabupaten Kerinci. Hal ini dijelaskan oleh nilai t hitung $>$ t tabel $(2,4470>2,021)$. 


\section{Saran}

Berdasarkan kesimpulan penelitian yang telah dikemukakan maka dapat disarankan :

1. Puskesmas kecamatan Depati VII kabupaten kerinci perlu meningkatkan disiplin kerja terhadap prestasi kerja pegawai sebab hal tersebut terbukti berpengaruh signifikan terhadap kinerja pegawai dan mampu menumbuhkan persepsi positif pegawai terhadap tempat mereka bekerja.

2. Dengan melihat hasil analisis yang menunjukkan bahwa pengaruh disiplin kerja terhadap prestasi kerja pegawai Puskesmas Kecamatan Depati VII Kabupaten Kerinci maka perlu diadakan riset lebih lanjut untuk meningkatkan efektifitas dan efisiensi.

3. Pada penelitian selanjutnya, penulis menyarankan untuk meneliti unsur-unsur disiplin yang lain, serta faktor-faktor lain yang dapat mempengaruhi peningkatan Kinerja Pegawai Negeri Sipil (PNS). Baik yang bersifat langsung maupun tak langsung serta hubungannya dengan peningkatan kinerja.

\section{UCAPAN TERIMAKASIH}

Terima kasih kepada team ojs Jurnal Administrasi Nusantara, LPPM SIA Nusa, STIA Nusantara Sakti Sungai Penuh, Kecamatan Depati tujuh, serta semua pihak yang tidak bisa disebutkan satu persatu. Sehingga jurnal ini dapat dipulikasi secara resmi.

\section{VI . DAFTAR PUSTAKA}

Arikunto Suharsimi, 2003, Prosedur penelitian suatu pendekatan praktek, PT. Aneka Cipta, Jakarta.

Asmiarsih, Desy.2006. Pengaruh pengawasan terhadap disiplin kerja Pegawai Badan kepegawaian Daerah Kabupaten Brebes. Skripsi, Fakultas Ilmu Sosial, Universitas Negeri Semarang. Semarang.

Ginting, Eva Flora, 2010. Pengaruh disiplin kerja terhadap prestasi kerja karyawan pada PT. Bank Rakyat Indonesia (Persero) Tbk Cabang Medan Putri Hijau. Skripsi, Fakultas Ekonomi. Universitas Sumatra Utara, Medan.

Hasibuan, Melayu SP.. 2005. Manajemen Sumber Daya Manusia, Rineka Cipta, Jakarta.

Mangkunegara. 2001.Manajemen sumber daya manusia. PT. Remaja Rosda Karya, Bandung.

Nasution, Mulia. 2000. Manajemen Personalia. Jakarta : Djambatan

Pedoman penyusunan SKRIPSI STIA-NUSANTARA SAKTI SUNGAI PENUH TAHUN 2012

Peraturan Pemerintan Republik Indonesia Nomor 53 Tahun 2010 tentang Disiplin Pegawai Negeri

Sastrohadiwiryo, Siswanto. 2002. Manajemen Tenaga Kerja Indonesia. Edisi pertama. Cetakan pertama, Penerbit Bumi aksara. Jakarta.

Saydam, Gauzali 2000. Manajemen Sumber Daya Manusia. Suatu Pendekatan mikro. Djambatan Djakarta.

Soeprihanto, John. 2001. Penilaian Kinerja dan pengembangan karyawan, yogyakarta:BPFE.

Sugiyono, 2003, Metode Penelitian Administrasi, Penerbit CV. Alfabeta Bandung 